Aletria, Belo Horizonte, v. 28, n. 1, p. 181-200, 2018

\title{
O Romance: entre a história oficial e a alternativa
}

\section{The Novel Between History and Story}

\author{
Renan Salmistraro \\ Universidade Estadual de Campinas, Campinas, São Paulo / Brasil \\ renansalmistraro@gmail.com
}

Resumo: Este artigo analisa duas hipóteses distintas a respeito do desenvolvimento histórico do romance no Ocidente. A primeira delas, a que parece ser a mais célebre, pode ser sintetizada pelo estudo $A$ ascensão do romance, de Ian Watt, que situa a origem do gênero romanesco na Inglaterra do século XVIII. No entanto, várias visões contrárias a essa tese surgiram no interior da própria crítica literária inglesa, especialmente os estudos de M. A. Doody (The True Story of the Novel: an Alternative History) e Michael McKeon (The Origins of the English Novel 1600-1740), apontando para uma "história alternativa" do romance, baseados no pressuposto de um desenvolvimento mais amplo da prosa de ficção, que remeteria aos textos da antiguidade e dos países orientais.

Palavras-chave: teoria do romance; realismo formal; romance moderno.

Abstract: This paper analyzes two distinct hypotheses regarding the historical development of the novel in the West. The first, which seems to be the most celebrated, can be summed up by Ian Watt's study (The Rise of the Novel), which situates the origin of the novel in $18^{\text {th }}$ England. However, several opposing views of this thesis emerged within English literary criticism, especially the studies of M. A. Doody (The True Story of the Novel: an Alternative History) and Michael McKeon (The Origins of the English Novel 1600-1740), pointing to an "alternative history" of the novel, based on the assumption of a wider development of prose fiction, which would refer to the texts of antiquity and Eastern countries.

Keywords: theory of the novel; formal realism; modern novel. 
Os diversos discursos sobre o romance são constituídos, em sua maior parte, por uma compreensão romanceada de seu desenvolvimento histórico. A ideia do romance como a forma do mundo moderno, apresentada em conexão com o surgimento do protestantismo e da burguesia capitalista, constituído a partir da deterioração da epopeia a forma do mundo antigo, por seu caráter fechado e oral -, é um dos exemplos clássicos desta história romanceada. O que há de mais pernicioso por trás deste romance da história do romance é que ele impede uma perspectiva dialética da história literária, isto é, impede uma noção entre o todo e suas partes. Dito de outra forma, romancear a história do romance oculta o caráter político de toda organização hierárquica dos gêneros literários. No âmbito do romance, a consequência imediata é ignorar o desenvolvimento marginal da prosa de ficção no mundo antigo e medieval.

$\mathrm{O}$ influente estudo de Ian Watt, $A$ ascensão do romance, que apresenta o surgimento do romance moderno como sintoma das transformações sociais infligidas pelo progresso da burguesia industrial inglesa no século XVIII, é um exemplo desta que parece ser uma compreensão do romance como uma forma enrijecida ou mesmo fossilizada. Com o termo realismo formal, Watt quer sustentar o realismo como o aspecto de distinção entre o romance moderno e as formas narrativas anteriores. No horizonte desta perspectiva está a busca pela correspondência entre a obra literária e a realidade que ela imita, o que, segundo Watt, determina algumas mudanças substanciais quanto ao funcionamento social das obras de arte. A primeira mudança seria a transição da tradição coletiva à experiência individual, pois enquanto os gêneros anteriores respondem à cultura e à tradição, o romance moderno abordaria a experiência cotidiana do indivíduo. Outra mudança decorreria desta centralidade do indivíduo: com a perda do aspecto completo e imutável da realidade, o enredo acaba desvinculado da mitologia, da história, da lenda ou de formas literárias do passado, como a épica e a tragédia. A terceira transformação (e talvez a mais frágil) é a hipótese de que o preço da fidelidade do romance à experiência humana ou à realidade da vida cotidiana é a ausência de convenções formais.

Desse modo, o realismo formal basicamente engloba um modo de percepção da realidade que tem mais a ver com a prática de observação do artista, do que com seu estilo. Em outras palavras, o realismo formal é mais uma questão de conteúdo - individualismo, vida privada e descrição exaustiva do cotidiano - do que de forma. O maior paradoxo 
de Watt está justamente nesta hipótese de que a suposta ausência de preocupação formal é o aspecto distintivo da forma romanesca. Assim, aquilo que distingue o romance ou aquilo que o romance faz melhor do que qualquer outro gênero é o "abandono das categorias estéticas", as quais, segundo Watt, afastam a arte da realidade. Para ele, a natureza prosaica do romance confia no relato, por isso ele se torna o palco de maior correspondência entre a obra literária e a realidade que ela imita.

Esta visão do romance não é uma exclusividade do estudo de Watt, tampouco da tradição inglesa. Ela está presente, por exemplo, no manifesto de Breton quando se refere à prosa romanesca como uma art facile. Inclusive, de tão presente, já foi muito combatida pela análise dos elementos estilísticos da prosa em autores como Jakobson, Blanchot ("Le roman, oeuvre de mauvaise foi") ou Kristeva (O texto do romance). Contudo, esta tese de Watt revela o mais próximo que o gênero romanesco esteve de articular em torno de si uma tradição. Tal momento circunstancial de seu desenvolvimento histórico tem mais a ver com a ascensão do capitalismo e com a implementação do modo de vida burguês do que o próprio realismo formal.

A tese de Watt está baseada no pressuposto de que as condições sociais da Inglaterra do século XVIII foram as mais adequadas ao surgimento do romance moderno, caracterizado pelo realismo formal. No entanto, também é possível pensar que foi o realismo, historicamente presente das mais variadas maneiras em inúmeras formas de expressão artística e não artística desde a antiguidade - como testemunham a História de Heródoto, as comédias de Aristófanes, os diálogos de Platão e os romances satíricos do período romano -, que se afirmou como o modo de expressão mais adequado aos interesses da burguesia inglesa emergente. Ou seja, ao invés de colocar o realismo formal como um evento estético inaugurado pela burguesia, é possível rever o realismo como um estilo mais ou menos disperso, presente em diversos níveis, de diferentes formas, em várias sociedades, sem muita atenção, assim como o romance, até que em determinado momento histórico serviu aos interesses de representação da classe dominante a ponto de ser meticulosamente sistematizado ao lado do gênero que lhe coube como invólucro: o romance.

Esta inversão da hipótese de Watt permite investigar os motivos de haver entre o romance e o realismo um elo tão forte a ponto de orientar as concepções sobre o gênero romanesco até hoje. Por outro 
lado, sustentar que o romance moderno surge com a burguesia industrial inglesa e que a sua premissa enquanto gênero é o realismo formal implica não só reconhecer, como Watt, a crise do romance em Henry Fielding, como descartar todas as formas de expressão em prosa do período que se afastaram do realismo formal. Esta perspectiva impõe um rompimento absoluto desde as expressões idealistas do romance grego até o fim do romance de cavalaria e o romance moderno, como se a burguesia inglesa iniciasse um mundo completamente novo a partir do nada, como se os valores da aristocracia tivessem se dissolvido de um dia para o outro, como se não houvesse nenhum paralelo possível entre o drama vitoriano, por exemplo, e as aspirações burguesas em torno da arte.

$*$

O primeiro forte indício para entender a canonização do romance sob o signo do realismo formal na sociedade burguesa é a predominante ausência de convenções formais ao longo de seu desenvolvimento histórico. Alheia às poéticas pelo menos até o período clássico, a ficção em prosa permaneceu às margens da sistematização. Como toda poética é orientada pela noção de sistema, de modo que a condição para o reconhecimento de determinado gênero é a sua obediência às leis que a própria poética institui - como o dogma da imitação e representação, a exigência de verossimilhança e a distinção clara do estilo na Poética de Aristóteles -, a marginalização do romance aponta para um potencial anticanônico (que acaba enormemente explorado pelo conceito da polifonia). A condição marginal do romance até o século XVIII deu a ele o privilégio de assumir a ausência de regras como seu único elemento constitutivo, o que fez dele um gênero com alta capacidade de assimilação e integração, a partir de uma técnica orientada especialmente pela paródia.

Por isso, a noção de criticidade que Watt atribui ao romance moderno, em oposição ao mundo idealizado pelos romances barrocos e medievais, está longe de ser um projeto exclusivo do realismo formal. Há um processo similar no mundo antigo entre o desenvolvimento do romance grego e latino. O Satiricon de Petrônio e O Asno dourado de Apuleio, por exemplo, parodiam o modelo do romance idealista grego. Embora não fique claro se a intenção de Petrônio é ridicularizar o gênero ou defender uma nova visão de mundo, sua obra, supostamente produzida para divertir a pequena corte de Nero, constitui-se como uma crítica aos valores morais da sociedade, o que a eleva a uma condição superior 
àquela de mero entretenimento. Holzberg (1995) defende que o mesmo é feito por Apuleio quando transforma o herói em anti-herói, elevando o romance a uma posição crítica, especialmente por recusar o acúmulo de aventuras que sempre culminava no final feliz.

Esta aproximação entre o romance satírico romano e o romance moderno acabou impulsionada pela linha genealógica que Bakhtin estabelece entre a sátira menipeia e o romance de Dostoievski, em Problemas da poética de Dostoievski. Daí vem sua hipótese do romance ser ainda um gênero por se formar ou em perpétuo desenvolvimento. No entanto, é difícil precisar o quanto esta compreensão da história do romance como um esvaziamento, uma redução, um ataque a tudo o que anteriormente se entendia por romance - isto é, como forma voltada para o futuro, todo romance seria uma redefinição do romance anterior - é tributária do aspecto marginalizado de seu desenvolvimento ou mera projeção de uma concepção moderna do romance. A hipótese da deterioração como o elemento definidor da forma romanesca está presente tanto na história usual do gênero, para a qual o romance se afirmaria com a paródia do romance de cavalaria (Amadis de Gaula) presente em Dom Quixote, quanto numa suposta "história alternativa", que ganhou força especialmente após a crise do romance realista, com a renovação do interesse pelos romances gregos e latinos, como se a antiguidade pudesse fornecer a estrutura original do gênero, tal como sugerido por Northrop Frye (1987).

Torna-se comum a esta vertente "alternativa" da história do romance identificar na epopeia elementos que a aproximariam da prosa moderna. Nessa perspectiva, Ulisses e Aquiles, por exemplo, tornam-se modelos de indivíduos desgarrados; o primeiro, por seu caminho errante na viagem de volta a Ítaca, que o aproximaria da busca do herói do romance; já Aquiles, por seu comportamento individualista, primeiro ao abandonar a batalha contra os troianos em virtude do conflito com Agamenon, em seguida por voltar a lutar ao lado dos gregos apenas após a morte de seu primo Pátroclo, movido por um desejo pessoal de vingança contra Heitor. O risco dessas aproximações no âmbito de uma "história alternativa do romance" está justamente em projetar uma concepção moderna do romance às formas do mundo antigo. Na verdade, a busca de Ulisses e o individualismo de Aquiles só podem ser identificados retroativamente, à medida que se tornam elementos estruturais importantes no romance moderno, sob a orientação de mundo burguesa. 
É importante destacar, por exemplo, que, apesar das intempéries pelas quais é acometido, Ulisses permanece sempre o mesmo, "astuto e valente". Os vinte anos que passou afastado de sua terra natal transformaram apenas seu corpo - é somente a velhice que impede a Telêmaco, Penélope e seus pretendentes reconhecerem na figura do mendigo sua real identidade. A memorável cena do encontro com o cão Argos é um indício forte do abismo entre a perspectiva temporal na Odisseia e aquela presente nos romances modernos. A situação de abandono na qual Ulisses encontra seu cão, que padecia em meio a esterco de vacas e mulas, velho e cansado, contrasta com a lembrança que tinha de seu belo porte, rapidez e bravura. Ela também simboliza a degradação da cidade com os anos de ausência de seu rei. Mas ao reconhecer Ulisses, pouco antes de expirar, acometido pela "negra morte", Argos revela que a essência de seu dono permanece intacta. Os vinte anos de ausência não enfraqueceram em nada a relação entre eles. Não é por acaso que esta cena antecede sua vingança contra os pretendentes: mesmo velho e debilitado pelos anos de errância, Ulisses age como o mesmo rei astuto que deixara Ítaca para lutar em Troia, somente a partir desta base inverossímil, Homero pôde dar a seu personagem condições para derrotar seus inimigos.

A condição heroica de Ulisses, cujo passar dos anos não promove deterioração nem acúmulo de experiências, contrasta inclusive com a tendência a ver na Odisseia uma inclinação à vida cotidiana, já que a situação de batalha não é mais um elemento central como na Ilíada. Apesar do tema da volta ao lar e da representação do cotidiano de Penélope com os pretendentes, o éthos da Odisseia é evidentemente heroico, pelo modo como caracteriza seus personagens e suas ações. O destaque da vida cotidiana em Homero é outro elemento estrutural que também só pode ser realizado retroativamente, a partir do momento em que ele se torna relevante para o romance burguês. É o olhar pela fechadura do romancista do século XVIII que faz da vida cotidiana um elemento importante da prosa de ficção, ao passo que seu desenvolvimento passa a ser identificado em formas anteriores de representação.

Ainda sobre a centralidade da vida cotidiana, que Watt atribui ao surgimento do romance inglês, Holzberg, por exemplo, sustenta que, exceto pela trama, os primeiros romances antigos também estão centrados na vida cotidiana. Para ele, essa condição reflete o momento histórico em que foram criados, no período helenístico. Com as primeiras invasões 
persas e posteriormente com o domínio romano, as cidades-estados gregas acabaram engolidas pelo aparelho político-social dos grandes impérios, nos quais o indivíduo tinha um papel pequeno na vida política. Enquanto a tragédia e a comédia antiga, no seio das cidades-estados, refletiam a experiência cívica, para Holzberg, o romance surge na era dos grandes impérios, como expressão da experiência individual, assim como a poesia helênica (de Parthenius) - que aborda as vicissitudes dos jovens amantes - e a nova Comédia (de Menandro) - com o retrato de problemas de identidade, peripécias amorosas e cenas familiares.

Esta aproximação entre a nova Comédia grega e o romance moderno, de acordo com a centralidade da vida cotidiana, não é um argumento recente nos estudos literários. Ela inclusive encontra respaldo nas análises históricas da civilização grega, como a de Toynbee (1959), para quem o enfraquecimento das cidades-estados, em virtude das guerras internas, tornou a vida pública um fardo para os indivíduos. Contribuiu para isso o estado de guerra permanente que fez com que a obediência às leis, a submissão ao treinamento e à disciplina militar e a disposição de arriscar a própria vida pelo Estado se impusessem como algumas das contribuições exigidas de forma contínua por causa dos conflitos intermitentes. O confronto entre a vida cívica e a consciência individual, segundo Toynbee, não foi amenizado antes do domínio romano, uma vez que a degradação moral pelo aspecto cosmopolita da ocupação macedônica não produziu apenas um deslocamento demográfico, com a leniência ante a migração a qualquer estado dominado pelos persas, como também um sentido de desamparo psicológico.

A busca do homem grego por novos valores, que é revista no âmbito da história alternativa do romance como a primeira divisão entre o público e o privado, é exemplificada pelo desafio de Sócrates à cidade-estado e herdada pelo senso de emancipação em Eurípides e Platão. Seria neste contexto de desamparo que a nova Comédia de Menandro e os romances idealistas gregos constituíram-se como uma comédia de costumes da vida da classe média da época. A possibilidade de aproximação entre o período de decadência do cidadão grego e a fase de emergência do homem moderno está justamente no fato de que a centralidade da distinção entre mundo externo e interno, ou do conflito entre indivíduo e sociedade, traduz o enfraquecimento dos valores morais e éticos, ou melhor, a ausência de formas de vida exemplares. Por isso, diferentemente da épica e da tragédia, o primeiro propósito do romance 
idealista grego era o entretenimento - mais do que expor os problemas do mundo, a imersão da vida cotidiana num universo de fantasia amorosa com final feliz auxiliava no esquecimento da unidade perdida.

Portanto, escolher entre a ascensão do romance burguês como o momento inaugural da história do romance ou a hipótese de um desdobramento do romance grego e latino naquilo que viria a ser o romance moderno não parece ser mais do que um gesto arbitrário. A escolha entre uma concepção ou outra está longe de ser uma abordagem eficaz do problema, uma vez que nessas duas caracterizações do desenvolvimento histórico do romance é possível identificar elementos de projeção da visão de mundo moderna. O romance como descrição prosaica da vida cotidiana, por exemplo, tal como preconizado por Watt, inaugura uma espécie de realismo prescrito, ou melhor, uma formulação que acaba estendida à ficção como norma, o que não condiz com o caráter marginal do romance. Por outro lado, a constatação de sua marginalidade propaga a ideia do romance como um gênero que usurpa os outros. Nesta posição, ele incorpora e repete ad infinitum o projeto de inovação moderna. É preciso ter em mente que sua marginalidade no mundo antigo lhe conferia um funcionamento muito diferente daquele do início do período moderno.

Por isso, o promissor nesta dicotomia entre a história oficial e a história alternativa é a possibilidade de constatar que não existe uma concepção clara e universal do romance. Ele precisa ser pensado em cada momento histórico, uma vez que não possui forma final nem tradicional, o que faz dele o epítome da natureza caótica dos gêneros literários. Mas esta sua condição continua obscurecida justamente pelo desenvolvimento do realismo formal, que é consequência da apropriação do romance pela burguesia emergente. É por investigar este aspecto da condição privilegiada do romance na sociedade burguesa que o estudo de Watt volta a ser interessante, apesar do equívoco de projetar o realismo formal como o elemento que inaugura o romance moderno.

$*$

A obra principal de Watt sustenta a ideia de uma concepção do romance que começa a tomar forma no período clássico, quando sua "ausência de regras" ou "marginalidade" foi encarada como problema. É neste momento que ele passou a ser rejeitado por sua "facilidade", foi acusado de degradar o espírito (pela representação do amor, que 
corrompe os modos) e de servir apenas ao ócio das donzelas. Tal ataque ao romanesco, movido pela nobreza influenciada pela arte renascentista, é sintetizado por Boileau em Diálogos sobre os heróis do romance (1668), em que ataca os romancistas por criarem personagens efeminados, sem grandeza, glória ou virtude cívica (nacionalismo militar), o que faz dele o primeiro a reconhecer o romance como empreendimento burguês. Mas esta primeira incursão do romance no campo da poética ocidental, pela influência de Boileau, não o relaciona somente à trivialidade da burguesia emergente, de modo que faltaria a ambos a grandeza da classe superior, como aponta para um processo de nacionalização do gênero que paradoxalmente será levado a cabo pela própria burguesia.

Enquanto a inclinação moral, que mais tarde tornará o personagem o elemento articulador do romance, denigre o romanesco, já constituindo uma clara predileção pela épica, o nacionalismo, por sua vez, obscurece a longa tradição da prosa, favorecendo a estreita ligação burguesa entre romance e realismo. Por isso, Doody (1996) interpreta a larga influência do pensamento de Boileau na tradição literária ocidental como um movimento político que nega as influências do Oriente sobre a prosa romanesca. É assim que a épica e Homero tornam-se os principais precursores do romance. Este movimento de entrada do gênero até então marginalizado na ordem da tipologia das poéticas alia o movimento de representação da vida cotidiana do realismo formal ao nacionalismo burguês e, consequentemente, a uma relação estreita do romance com as tradições literárias ocidentais canônicas (como a épica e a tragédia).

Doody entende este movimento como um sinal da ambivalência do doméstico no século XVIII: o doméstico possui um primeiro sentido de se referir à esfera doméstica, mas há também o sentido nacionalista do termo. É justamente neste último sentido que a necessidade de naturalizar o gênero pela história literária nacional faria dele uma forma própria, como proposto por Watt. Por isso a grande habilidade do romance realista doméstico inglês é a exclusão do outro, ou seja, qualquer romance que não seja doméstico é excluído da definição de novel. Para exemplificar esta situação é interessante aproximar a visão de Boileau daquela apresentada por Huet, em Tratado da origem dos romances (1670), que surgiu como a primeira tentativa de situar as origens do gênero romanesco. Para os defensores de uma história contínua do romance, o estudo de Huet interessa num primeiro momento por atribuir a origem do gênero romanesco ao espírito inventivo do homem, que seria 
traduzido pela inclinação às histórias de amor. Inspirado pelo Aethiopica de Heliodorus, que é o romance grego de maior influência sobre os romances de cavalaria, inclusive é parodiado em Trabalhos de Persiles de Cervantes e no Cândido de Voltaire, Huet define o romance como histórias inventadas sobre aventuras amorosas, escritas em prosa, para o deleite e instrução dos leitores. ${ }^{1}$ A noção de deleite conserva o aspecto de "entretenimento" do romance grego, como sugerido por Holzberg e Toynbee, ao passo que a "instrução" já aponta para o aspecto moralizante do período clássico.

Então, no Tratado de Huet, o amor aparece como o elemento civilizador do homem, que orienta tanto sua curiosidade em relação ao mundo, quanto sua integração social. No entanto, o aspecto mais relevante das reflexões de Huet acabou ocultado pelo classicismo de Boileau, a saber: sua crença no caráter multiétnico e poliglota da prosa de ficção, cujas origens estariam no Oriente próximo. Em pleno século XVII, Huet falava nas raízes orientais do romance, bem como na influência árabe em sua disseminação pela Europa a partir da península ibérica, perspectiva que foi progressivamente eclipsada à medida que o romance deixava de ser um gênero periférico. Doody explora este processo de reconhecimento do romance como um gênero propício para o debate de ideias e comportamento como indício de sua limitação à história literária ocidental. Por isso, a perspectiva de Huet, por contribuir para que o romance fosse encarado como coisa estrangeira, que desvaloriza a civilização e desfaz centralidades, alimentava tudo o que os valores católicos, anglicanos, protestantes e puritanos alertavam como os "perigos" do romance - isto é, aquilo que pertencia aos outros, ao baixo, ao bárbaro precisava ser suprimido.

Alvo dos valores protestantes, o romance passou a ser não só distração, como perigo moral. Assim ele logo acabou impregnado pela orientação prescritiva e classificatória da poética aristotélica, que também implicava a distinção entre os eventos baixos e o ideal platônico da verdade. Desta junção entre um gênero historicamente marginalizado que reuniu em torno de si um apelo à mediocridade - e a inclinação ao estabelecimento de dogmas - tanto ao nível literário quanto social, de uma elite influenciada pelos valores renascentistas - surgiu o realismo formal como a primeira tentativa sistematizada de definir o que é o romance.

${ }^{1}$ THOREL-CAILLETEAU. The Poetry of Mediocrity, p. 64-94. 
Nesta perspectiva, o estudo de Watt ajuda a compreender o que é feito do romance com a ascensão da burguesia.

Logo no início de A ascensão do romance, há um paralelo entre o realismo formal e o realismo moderno de Descartes e Locke. Com isso, Watt apregoa que o realismo surge como uma representação verdadeira dos objetos, isto é, representa aquilo que existe e que se pode ver, contrário à ideia da escolástica, segundo a qual só é real a essência. Se o realismo declara a realidade dos objetos dos sentidos, Watt conclui que ele reflete plenamente o conceito cartesiano do método: a busca da verdade dependeria do indivíduo, que antes deve romper com os entraves da percepção. Consequentemente, o termo se afirma como um sólido senso das coisas existentes oposto ao caráter lúdico da vida, trata-se, portanto, de uma atenta observação do concreto e dos objetos da vida cotidiana.

Em resumo, o realismo formal seria a reivindicação de que a verdade artística está na representação dos objetos. Esta visão implica numa série de transformações estruturais da narrativa, a começar pela predicação do autor como uma figura impessoal. Em nome da objetividade, o ideal é que ele não condene nem julgue, mas que apenas exponha os fatos. Já a aproximação da vida cotidiana, em detrimento da fantasia e do fantástico de aventuras, exalta os personagens como figuras contemporâneas, individualizados por sua época e por sua classe. As descrições servem para caracterizá-los e para "sublinhar a representação da vida tal como ela é". Se os personagens são contemporâneos, cercados por objetos da realidade cotidiana, Watt então repete como método do realismo formal o postulado de Engels sobre Balzac: a representação de pessoas específicas em circunstâncias específicas. Assim há não só uma transformação dos agentes no enredo e do local de suas ações, como do próprio enredo, concebido por Watt nos termos defendidos por E. M. Foster em Aspectos do romance, como uma descrição da vida através do tempo.

O mais interessante no estudo de Watt está nesta inter-relação estabelecida entre todas essas mudanças estruturais da narrativa e a ascensão burguesa, o que significa que a ordem racionalista, sistemática e coerente da narrativa reflete a tomada de poder pela burguesia. A importância do fluxo temporal, por exemplo, explicita que se não há verdades imutáveis, não haveria razão para histórias atemporais. A restrição aristotélica da ação da tragédia a 24 horas demonstra que a verdade podia revelar-se inteiramente em um dia ou em uma ação da vida humana. Este aspecto atemporal só é possível numa sociedade 
sustentada pela tradição e apoiada na conservação da crença na existência real e imutável por trás das aparências, tal como a descrição platônica do mundo das ideias.

Watt, por sua vez, esclarece como a temporalidade ocupa uma posição central no romance em virtude do individualismo, intensificado no capitalismo industrial, uma vez que pressupõe independência entre as pessoas e das pessoas frente à tradição, o que depende da liberdade econômica e social. Para Watt, apenas o capitalismo industrial forneceu a estrutura socioeconômica do individualismo, por tornar o indivíduo responsável por seus papéis político, econômico, social e religioso. Esta visão apresenta Crusoé como o estereótipo do capitalista que prospera através do esforço individual. Mas Moretti mostra em O burguês, que a corporificação humana do capitalismo - o burguês - desaparece ao passo que seu sistema econômico avança. Como resultado, o romance burguês tende a tornar-se outra coisa, mesmo no interior da sociedade burguesa.

Portanto, mesmo aquilo que o estudo de Watt tem de mais interessante não pode ser levado às últimas consequências. Ele não se preocupa em explicar, por exemplo, como o individualismo, que naquele momento de ascensão do romance colocava todas as peças do realismo formal em movimento, viria a colocar em xeque o próprio realismo, justamente pelo potencial desagregador do indivíduo diante de uma visão de mundo objetiva. Quando chega a Fielding, a solução de Watt é colocar o romance em crise, por seu distanciamento do realismo - atitude que também será tomada por Lukács em $A$ Teoria do romance, pelo mesmo efeito desagregador do indivíduo. Em outras palavras, quando o romance burguês afasta-se da burguesia e do realismo formal, ele não serve mais aos critérios de Watt.

O realismo formal deve conter a opção por "descrever o mundo visto" em detrimento da "imitação de ações humanas significativas", o que desloca o resultado da arte das grandes cenas, da história sagrada e profana para situações triviais. Este movimento é o que Moretti chama de "sério", ou melhor, é aquilo que faz o século da ascensão da burguesia o "século sério". ${ }^{2}$ Watt parte deste mesmo ponto para a hipótese de que a fidelidade ao aspecto físico da realidade encobre a preocupação formal, por isso condena Fielding por seu "estilismo", que desviaria a atenção do realismo à forma. Contudo, a crítica a Fielding vai além de atacar

${ }^{2}$ MORETTI. Serious Century, p. 364-400. 
sua preocupação formal, uma vez que para Watt a "epopeia cômica em prosa" corresponde menos às transformações sociais que à tradição neoclássica, já que seria uma aproximação teórica e abstrata, sendo que a feição de um gênero oral e poético que aborda as façanhas de figuras públicas nada teria em comum com Defoe e Richardson.

Fielding pode ser pensado de uma outra perspectiva: como aquele que faz a primeira crítica ao realismo formal. E nessa posição, ele é um homem do seu tempo e um precursor do caminho que o romance percorrerá no período de decadência burguesa. Isso porque o enfraquecimento da legitimidade do burguês não coincide com o arrefecimento do capitalismo. Moretti mostra que acontece justamente o contrário: o recrudescimento do capitalismo é concomitante à perda do prestígio da classe burguesa - que primeiro conduziu a guerras e a massacres; após a guerra promoveu regimes democráticos que enfraqueceram a ideia de classe dominante; por fim, a mercadoria erigiu o consenso sobre coisas, não sobre pessoas.

Então é possível concordar com Watt até o ponto em que o realismo formal surge como parte de um momento histórico específico - aquele da ascensão da burguesia -, mas é necessário evitar a ideia do realismo como o pressuposto do romance de modo geral. $\mathrm{O}$ grande legado do romance burguês não são as formas de composição do personagem, do enredo e da temporalidade da narrativa. O próprio Watt mostra que os imperativos do realismo formal resistiram por muito pouco tempo. O que permanece desse período é o fortalecimento de valores como probabilidade e verossimilhança, que mudam o modo como a ficção é compreendida em relação à realidade e à história. Esta nova lógica da ficcionalidade começa a ser desenvolvida pela distinção típica em língua inglesa entre romance e novel.

A distinção entre romance e novel na tradição anglo-americana se baseia nas transformações da ficcionalidade. ${ }^{3} \mathrm{O}$ novel é a forma que explicita a condição fictícia do romance, o que já aparece no realismo de Defoe, cuja aspiração de ser "a history" em vez de "a story" força o reconhecimento do aspecto ficcional da obra de arte. Assim, Defoe assume a narrativa como uma mentira, mas como o uso da ficcionalidade é

${ }^{3}$ GALLAGHER. The Rise of Fictionality, p. 336-363. 
suportado em princípios morais e religiosos, a ficção não seria desprovida de verdade. Por não propor a (falsa) historicidade dos fatos de Crusoé, Defoe redefine o romance: uma mentira sim, mas que conduziria à verdade. O paradoxo do novel está justamente em revelar e esconder a ficcionalidade: assume sua condição fictícia para reclamar-se verdadeiro. Este paradoxo sustenta-se pela oposição que o novel assume em relação ao romance, cuja aproximação da fantasia, por recorrer às fábulas, alegorias e contos de fada, suspende a referencialidade, ao passo que o pacto do novel com o cotidiano tende a ser visto como verdadeira, seja por reproduzir fatos reais ou por remeter a eles. Em The Origins of the English Novel, McKeon explora o modo como esta abertura do novel ao cotidiano exige uma conceituação da ficcionalidade pelo próprio romancista, uma vez que a distinção entre verdade e mentira fica menos visível. Mckeon então entende o movimento do romance medieval ao romance moderno como uma troca epistemológica da construção da verdade como fato histórico para a verdade como efeito da simulação mimética.

Mas o confinamento do romance ao maravilhoso da aventura ou à fantasia não oculta aquilo que ele possui de prosaico. A própria derivação do termo romance da palavra francesa roman, que expressa a linguagem na qual esses textos foram escritos, uma linguagem que ainda não era vernácula, mas também não era mais o latim, sugere sua inclinação ao popular. Romancier significa expressar-se numa linguagem mista, refinada, mas profana, portanto, o termo romance expressa que entre o humano e o divino, ele tende à mediocridade da vida terrena. Thorel-Cailleteau parte desta definição para mostrar que já há em Huet a defesa de uma "poética da mediocridade". Mas para ele, o romance deveria conservar certa dose de idealismo, tendo em vista que na realidade o bem nem sempre vence. Por isso, apesar de representar personagens comuns em circunstâncias banais, o romance não poderia deixar de divertir ou instruir o leitor.

Já o termo novel, que deriva das línguas românicas - como do italiano novella, empregado por Boccaccio no Decamerão -, agrega ao aspecto prosaico do romance o sentido de News, notícias e novidades, que remetem num primeiro momento às histórias contadas pelos comerciantes. Somente no século XVI, sob influência do Decamerão, o termo passa a ser empregado para designar textos fictícios e logo depois passou a se referir a textos longos em prosa, mas opondo-se ao francês romance e ao italiano romanzo, por estar mais ligado ao cotidiano. A 
língua inglesa então herda esta distinção que oculta o verdadeiro motivo pelo qual o romance moderno se consolida: não pelo realismo, mas pela ênfase nas leis da sua ficcionalidade.

É nesta perspectiva que Henry Fielding, antes encarado pela ótica do realismo formal como exemplo da decadência do romance burguês, aparece agora como o principal precursor do momento em que o romance moderno toma consciência de si mesmo. Esta questão da referencialidade pode ser identificada de modo bem simples pela forma de nomear os personagens: Robinson Crusoé, como um personagem com nome e sobrenome potencialmente reais, é ao mesmo tempo uma identidade fictícia e uma figura possível de existir no mundo, o que sugere que em Defoe, a linha divisória entre o fictício e o real ainda é tênue e pouco explorada. Já Fielding se dispõe a criar tipos, cuja função de representar uma "espécie" (humana ou social) sobrepõe ao homem no mundo a condição fictícia do personagem: Tom Jones, Joseph Andrews, Shamela são abertamente categorias literárias, que escancaram a referencialidade do romance.

Por isso, a partir de uma perspectiva dialética do desenvolvimento histórico do romance, o que significa apreender o objeto de análise tanto numa perspectiva de continuidade quanto de descontinuidade, McKeon considera que Fielding encerra a pré-história do romance burguês, cujas características seriam consolidadas somente no século XIX. Com isso ele espera recolher as aparas deixadas por Watt quando este relaciona as premissas do realismo formal com o realismo filosófico, mas também com as transformações socioeconômicas do período. Para McKeon, a luta da burguesia por legitimidade e seu desejo por representação é menos propícia ao realismo que à incorporação pelo romance de questões relacionadas tanto à significação da virtude quanto da verdade. Entre uma questão moral e outra epistemológica, a formação do romance moderno confrontaria simultaneamente as crises sociais e intelectuais do período.

Dentro daquilo que chama de "questões de verdade", McKeon defende uma visão sobre o desenvolvimento histórico do romance moderno aberta à sua origem caótica e inexata. Assim ele chama a atenção para o caráter impreciso de termos como "romance medieval", "história" e "romance moderno" ainda no século XVIII. Se por um lado a necessidade de opor romance e história sublinha as oposições entre estas duas maneiras de abordar a "verdade", por outro, ela evidencia suas semelhanças. Como o romance medieval não trabalha com a distinção 
entre o que era fato ou ficção, as indagações sobre o tratamento da verdade na narrativa começaram a ser aperfeiçoadas somente no século XVII. A aparência de completude do romance medieval deriva justamente da presença do maravilhoso ao lado do histórico, que fez com que ele não se mantivesse fiel, tampouco desvinculado da história.

Apenas com a retomada do passado clássico pela Renascença e com a ruptura histórica promovida pela reforma protestante a consciência histórica começou a ser forjada com certo distanciamento da ficção em prosa. Por outro lado, McKeon lembra que o desenvolvimento da imprensa, que criou a impressão de que o conteúdo impresso era objetivo, contribuiu para obscurecer a realidade fictícia do romance conforme o número de publicações aumentava. É então pela relação do novel com a notícia (News, novella) que o equilíbrio entre história e verdade tornou-se suspeito, uma vez que as notícias já carregavam a ambivalência entre a objetividade dos fatos e a abstração dos textos fictícios.

Nesta perspectiva, a propensão burguesa ao realismo formal confunde-se com a defesa do romance moderno como uma questão de verdade, ou melhor, como resultado da observação empírica do mundo. Este clamor pela historicidade é o que marca, por exemplo, a passagem do romance heroico para o roman à la clef, mas também permite o desenvolvimento crítico da noção de verossimilhança, através da suspensão de uma oposição inequívoca entre romance e história, fato e ficção, abstração e verdade. Esta ambiguidade está presente, por exemplo, em Orlando Furioso, à medida que a descoberta do manuscrito pode ser pensada como uma paródia do historicismo, ao mesmo tempo em que a retórica do poema refuta abertamente os mitos da cavalaria por seu vínculo à imaginação.

O enriquecimento do valor da verossimilhança está por trás da consolidação do realismo. Com ele, a distinção entre romance e história começa a ser desenvolvida, a ponto de permitir que a narrativa seja encarada como não pertencente à história, mas desenvolvida como história, ou seja, como um conjunto de fatos prováveis e universais. Por isso mesmo, a afirmação do realismo não foi desprovida de preocupações teóricas, estilísticas e poéticas, uma vez que envolvia a redefinição de um gênero literário até então marginalizado. $\mathrm{O}$ aspecto formal do romance nesse momento de ascensão da burguesia ganha tanto destaque, que é pela forma que Mckeon analisa sua simbiose com a classe burguesa. Estas considerações são desenvolvidas no tópico sobre as "questões de virtude". 
Para Mckeon, o romance afirma-se como a principal forma para expressar a falta de convicção da nova ordem burguesa, tendo em vista que a gradual decadência da ideologia aristocrática, cuja distinção social era baseada na honra, que por sua vez derivava da linhagem do indivíduo e do poder político de seus ancestrais, corresponde a uma preocupação com a mobilidade física e social do indivíduo, já presente no romance grego circunscrito sobre a temática amorosa. As metamorfoses do amor, das viagens e das mudanças sociais coincidem, segundo Mckeon, com o desenvolvimento do comércio, cujo aumento da riqueza torna instável a questão da linhagem aristocrática. Então esta onipresença do romanesco e do mundo do comércio, pelo menos desde o século XII, leva Mckeon a analisar um longo período de fermentação da ideologia burguesa e de sua principal forma de expressão literária, bem como a pensar os períodos revolucionários não como a afirmação de uma classe em conjunto com o declínio imediato da outra, mas como um momento de instabilidade da ideologia dominante.

Esta noção de instabilidade ideológica acaba sendo fundamental para pensar a forma romanesca como aquela que interioriza a antítese dialética entre a ideologia progressista (burguesa) e a conservadora (aristocrática). Nestes termos, o romance possui uma "constituição dialética", a qual Mckeon identifica na dualidade das visões de mundo de Dom Quixote e Sancho Pança. É comum pensar a obra de Cervantes como aquela que inaugura o romance moderno, em função da capacidade de autocrítica que ele adquire de seu próprio procedimento formal, mas nele a irrealidade do romance de cavalaria sempre acaba conciliada com a vida cotidiana, seja pela loucura de Dom Quixote, que abre espaço para a fantasia, seja pela visão materialista de Sancho Pança, que devolve à vida sua banalidade. Enquanto o delírio lança Dom Quixote num mundo de aventuras - tomando moinhos de vento por dragões, ovelhas por cavaleiros encantados, viajantes por elmos -, Sancho identifica ao fim de cada batalha o inimigo real. E só parece aceitar os devaneios de seu mestre pela promessa de uma ilha e riquezas, em nome das quais abandonou mulher e filhos.

Reforça esta posição de Sancho como a antítese epistemológica do idealismo a própria origem castelhana de seu nome, que pode significar "prudência, sensatez, caráter, santo". ${ }^{4}$ Já a intensidade com que Dom

${ }^{4}$ CERVANTES. D. Quixote, p. 116. 
Quixote se lança em suas aventuras não pode ser desvinculada da condição em que fora acometido pela leitura de romances de cavalaria: "[...] e, assim, do pouco dormir e muito ler se lhe secaram os miolos, de modo que veio a perder o juízo". ${ }^{5}$ Dessa forma, ele assume uma perspectiva alegórica do modo como no romance medieval fato e ficção estavam associados. Dom Quixote se apropria da ficção como delírio, ao passo que Sancho Pança já é capaz de utilizá-la como artifício. Uma das passagens mais cômicas deste uso aparece no capítulo XX quando, com medo do escuro, ele implora para que seu mestre espere o amanhecer, antes de continuar o trajeto. Vendo o Cavaleiro da Triste Figura irredutível, Sancho sorrateiramente amarra Rocinante a uma árvore, sem que seu mestre perceba. Sem entender por que não consegue sair do lugar, Dom Quixote ouve de seu fiel escudeiro uma justificativa fictícia que encobre seu engenho: "Eia, senhor, que o céu, comovido das minhas lágrimas e rogos, ordenou que Rocinante não se possa mover". ${ }^{6}$

Se a ficção como delírio pode representar o comportamento do leitor da Idade Média, a ficção como artifício inaugura as expectativas do leitor do mundo moderno. É fundamentalmente pela consciência que desenvolve a respeito de sua própria ficcionalidade que Dom Quixote inaugura uma nova fase no desenvolvimento histórico do romance. McKeon explora este mesmo processo da ascensão do romance inglês - a qual ele reduz ao conflito entre Richardson, adepto do historicismo, e Fielding, que assim como Cervantes, inviabiliza o acesso do romance à veracidade dos fatos. Enquanto em Pamela, Richardson se vale da narrativa epistolar para manter o paralelo entre ficção e história, em Shamela, Fielding demonstra que os documentos nos quais a historicidade de Pamela se sustenta são falsos. Mas aqui não cabe alongar-se demasiadamente nesta disputa, afinal a importância desta revisão do conceito de realismo formal está em realçar a ambivalência da forma romanesca, ou melhor, o modo como o realismo se insere num percurso historicamente feito de muitas disputas e pouca consolidação.

A função de Sancho Pança em Dom Quixote e a singularidade de Fielding no momento de ascensão do romance inglês moderno realçam o desenvolvimento da ficcionalidade e da verossimilhança, estruturas fundamentais para o surgimento do leitor moderno, como aquele que é

\footnotetext{
${ }^{5}$ CERVANTES. D. Quixote, p. 57.

${ }^{6}$ CERVANTES. D. Quixote, p. 257.
} 
dissuadido a acreditar na verdade literal da narrativa. Com isso, a condição básica da modernidade é a exploração do como se, que por sua vez, como demonstra Gallagher, acaba sendo um recurso básico da vida moderna: do comerciante à mulher cortejada, o exercício da suposição torna-se comum em todas as áreas da sociedade burguesa ("Será que venderei meus produtos hoje?"; "será que ele realmente me ama?"). Consequentemente, a experiência de ler um romance é intrínseca tanto à descrença quanto à veracidade dos eventos, o que não significa descompromisso com a verdade, mas antes a exigência de uma percepção capaz de entrar no jogo de linguagem da ficção. Este é o outro paradoxo do romance moderno: sua forma abertamente ficcional oferece um caminho único à realidade, uma realidade que não está diretamente dada à compreensão.

A consciência de sua própria ficcionalidade torna o romance apto a se transformar, assumindo-se assim como um gênero voltado para o futuro, contra qualquer interesse em fossilizar sua forma. Nesta perspectiva, a verdadeira crise da forma romanesca poderia estar naqueles discursos que tomam os momentos de ascensão e consolidação da classe burguesa como momentos de canonização do romance, pelo amparo, num primeiro momento, do realismo formal e, na sequência, do alto realismo do século XIX - períodos em que ele mais foi exposto aos esforços de sistematização e definição globais. Esta perspectiva esconde as tensões internas dessas fases do desenvolvimento burguês ou, como diria Mckeon, não oferece uma perspectiva dialética da transformação histórica do romance. Qualquer análise que se dedique a investigar a relação das partes com o todo pode perceber que outras formas de romance surgem no período mais fértil do realismo como resposta às suas leis: a ficção científica, por exemplo - na qual sobrevivem aspectos da literatura oriental -, a memória pornográfica, o romance gótico, a narrativa fantástica, etc.

Mesmo os escritores mais representativos do estilo realista afastaram-se dos imperativos do realismo em algum momento, como Dickens em A Christmas Carol, Balzac em La peu de chagrin ou Flaubert em Salambô. Este movimento sintetiza o potencial de inovação que a consciência da ficcionalidade incorpora ao romance. Se Dom Quixote é apresentado como representativo do moderno por seu potencial de ruptura e inovação, o realismo formal preconizado por Watt e o romance realista francês representariam, na trajetória do romance, uma espécie de ruptura com o ideal do romance moderno, ao impor normas antes inexistentes ao gênero romanesco. 


\section{Referências}

CERVANTES, Miguel S. D. Quixote. Tradução de Sérgio Molina. São Paulo: Editora 34, 2012. 2 v.

DOODY, M. A. The True Story of the Novel: An Alternative History. New Brunswick: Rutgers University Press, 1996.

FRYE, Northrop. The Secular Scripture: A Study of the Structure of Romance. Harvard: Harvard Press, 1987.

GALLAGHER, Catherine. The Rise of Fictionality. In: MORETTI, Franco (Ed.). The Novel: History, Geography, and Culture. New Jersey: Princeton University Press, 2006. v. 1. p. 336-363.

HOLZBERG, Nikklas. The Ancient Novel: An Introduction. London: Routledge, 1995.

HOMERO. Odisseia. Tradução de Christian Werner. São Paulo: Cosac Naify, 2014.

McKEON, Michael. The Origins of the English Novel 1600-1740. Baltimore: John Hopkins, 2002.

MORETTI, Franco. O burguês: entre a história e a literatura. São Paulo: Três Estrelas, 2014.

MORETTI, Franco. Serious Century. In: . Franco (Ed.). The Novel: History, Geography, and Culture. New Jersey: Princeton University Press, 2006. v. 1. p. 364-400.

THOREL-CAILLETEAU, Sylvie. The Poetry of Mediocrity. MORETTI, Franco (Ed.). The Novel: History, Geography, and Culture. New Jersey: Princeton University Press, 2006. v. 2. p. 64-94.

TOYNBEE, Arnold J. Hellenism: The History of a Civilization. London: Oxford, 1959.

WATT, Ian. The Rise of the Novel. London: Pimlico, 2000.

Recebido em: 20 de dezembro de 2017. Aprovado em: 13 de março de 2018. 